\title{
Intergenerational differences in customer engagement behaviours: An analysis of social tourism websites.
}

\begin{abstract}
This paper explores differences among generations $\mathrm{X}, \mathrm{Y}$, and $\mathrm{Z}$ in customer engagement behaviours. Specifically, it analyses differences in customer behaviours in social tourism websites and the effects of self-efficacy and satisfaction on these behaviours. Based on an empirical study with a sample of 346 social tourism websites users, the results show that, in Generation X, self-efficacy exerts a higher effect on WOM than the other generations. In Generation Y, satisfaction influences information searches and hotel bookings more than for the others. Generation $\mathrm{Z}$ is more prone to give referrals than the other two generations.
\end{abstract}

Keywords: generations; social tourism websites; customer engagement; self-efficacy; satisfaction

\section{Introduction}

In the last few years there has been an increasing interest in generational analysis to understand customer behaviour in tourism (Huang and Lu, 2017; Luna-Cortés, 2018). Most previous research focuses on intergenerational differences with regards to destination preferences ( $\mathrm{Li}$ et al., 2013; Huang and $\mathrm{Lu}, 2017$ ) and information search (Beldona, 2005; Li et al., 2013; Huang and Lu, 2017). In the specific context of online platforms, the literature has mainly examined differences between generations in the content creation of online reviews and the use of other travellers' content (Amaro et al. 2016; TripAdvisor, 2016). However, there is a need to analyse generational differences from a broader viewpoint, including the recently defined Generation Z, and to study customer engagement behaviours, such as providing feedback to companies and spreading WOM.

The main purpose of this paper is to analyse the differences between Generations $\mathrm{X}, \mathrm{Y}$ and $\mathrm{Z}$ in customer engagement behaviours in social tourism websites. These websites are tourism-specific social media sites, such as Booking, TripAdvisor and Expedia, that allow customers to share their travel experiences. Specifically, the goals of this research are twofold. First, to analyse the effect of the variable generations in customer engagement behaviours; Second, to study the moderating effects of the variable generations in the relations between self-efficacy and customer engagement behaviours and between satisfaction and customer engagement behaviours in these websites. In the previous literature, both self-efficacy and satisfaction have been considered crucial antecedents of customer engagement behaviours. Specifically, self-efficacy is particularly important to explain customer behaviours in technological environments (Cheung and Chan, 2000; Vijayasarathy, 2004) and satisfaction is probably the most commonly used variable to explain behaviours such as purchase, repurchase, spreading WOM or giving referrals (Verhoef et al., 2002; Pansari and Kumar, 2016). Therefore, this study analyses the moderating effect of generations with these variables. 
From an academic perspective, this work contributes by analysing the differences and similarities between the generations in customer engagement behaviours in the light of contextual differences. From a managerial point of view, our findings can help managers of social tourism websites segment customers based on generational differences.

\section{Literature review}

\subsection{Generational cohorts}

A generation is defined as an "aggregate of all people born over roughly the span of a phase of life who share a common location in history and, hence, a common collective persona" (Strauss and Howe, 1997; p. 61). Generational cohort theory was originally developed by Mannheim (1952) and assumes that a generation of individuals shares the same set of values, attitudes, and behaviours, as a result of experiencing the same economic, political, and social events in their formative years (Inglehart, 1977).

Generation $X$, also referred to as 'Gen $X$ ', is defined as people born between the midsixties and the late-seventies (Berkup, 2014). They have experienced historical events, such as the moon landings and the fall of the Berlin Wall, they have learnt to tolerate the diversity of the changing world and have gained more creativity, as they grew up in more restricted environments than subsequent generations (Berkup, 2014). As a consequence of contextual factors, such as broken homes and workaholic parents, this generation is particularly individualist, it engages in financial planning, and has high self-reliance (Berkup, 2014; Wiedmer 2015). Gen $X$ has also gone through the technological revolution and important media developments. Individuals from this generation have seen the growth of TV and computers during childhood and adolescence (Li et al., 2013) and information from mass media is important to them (Gardiner et al., 2014). They have also experienced the arrival of the Internet. In fact, they are the first digital immigrants.

Generation Y, also known as 'Gen Y', or 'millennials', were born between 1980 and the mid-nineties (Berkup, 2014). Marjanen et al. (2019) characterised individuals from this generation as highly consumption-oriented, with sophisticated tastes and shopping preferences. This generation sees work as less central to their lives, and they are more prone than previous generations to leave their jobs if they are seen as boring or lacking in meaning (Maital, 2014). Generation Y is well-informed, investigative and loyal (Li et al., 2013) and heavily influenced by their peers (Nusair et al., 2012). This generation wants to build relationships with the brands they buy, so that companies need to create brands that are cool, real, unique, inspire happiness and allow identification between the customer and the brand (van den Bergh and Behrer, 2011). With regards the use of technology, people from this generation have witnessed the widespread growth of the Internet while they were adolescents and young adults (Li et al., 2013; Berkup, 2014). Despite technology being part of their daily lives, and that they are known as 'digital natives', they were not born into it, but migrated to the digital world at a very early age. Time magazine (2013) labelled Gen Y as the 'me-me-me generation' for its narcissism.

Finally, Generation Z, also referred to as 'Gen Z', is usually defined as those born after the mid-nineties (Berkup, 2014). Due to the fact that most individuals of this generation are still under age, it is difficult as yet to define their characteristics (Berkup, 2014). However, contextual factors are shaping their personalities. Generation $\mathrm{Z}$ has grown up in a world marked by the late economic crisis, and they show greater tolerance to aspects 
such as LGBT rights than previous generations (EY, 2015). They are more committed to helping others and the environment, and more inclined to group action, as they are aware of their role in the world and their responsibility to help to improve it (EY, 2015). Possibly the most defining characteristic of this generation is their ubiquitous use of technology. Members of Generation $\mathrm{Z}$ are marked by their use of the Internet, as it is part of their lives, education and their way of socialising. In fact, they are the first true digital natives. Living in the era of social networks and mobile devices makes Generation $\mathrm{Z}$ more prone to engage in social interaction and to co-create experiences in the virtual world than previous generations (Skinner et al., 2018). However, this use of technology has also produced an efficient but impatient generation that wants everything quickly (Berkup, 2014).

Despite the differential characteristics of the generations, it is difficult to predict their engagement behaviours in social tourism websites. As Generation Y experienced the rise of the Internet and social tourism websites when they were young, it is expected that they will search for information, book and write comments on these websites more than Generation X. However, previous studies have shown that this is not always the case. For instance, Li et al. (2013) found that Generation X considered online travel information sources more important than does Generation Y. This is contrary to the results obtained by Huang and $\mathrm{Lu}$ (2017), who found that the Internet, when searching for travel information, was more favoured by younger than by older generations. Other studies have suggested that the Internet is the most important travel planning tool across all generations (Xiang et al., 2015). Regarding online bookings, Xiang et al. (2015) found that Generation $Y$ makes reservations online and uses online travel agencies more than the other generations. However, TripAdvisor (2015) showed that Generation X books more travel online than Generation Y. It is expected that Generation $\mathrm{Z}$ will be more likely to give referrals because they are more familiar with social networks; this marketing tool is therefore especially suitable for them. All in all, it can be expected that Generation X, Generation Y, and Generation Z behave differently in social tourism websites. Thus, we propose the following research question:

RQ1: Does generation effect customer engagement behaviours in social tourism websites?

\subsection{Customer engagement behaviours and their determinants}

The study of customer engagement behaviours is of managerial interest, as it covers "the different activities of the customer that affect a firm's performance" (Pansari and Kumar, 2016). There are studies into social tourism websites that consider customer behaviours as forms of engagement, with most of them focusing on content creation (writing comments, rating services) and WOM (Casaló et al., 2010; Wei et al., 2013). However, Pansari and Kumar (2016) encourage researchers to consider other behaviours, such as booking a hotel, providing feedback, or giving referrals. Each time a customer books a hotel through a website, the company may earn a commission from the hotel. Similarly, customers may provide feedback to the website and give referrals to other people who might become users of the website. These activities are beneficial for tourism companies, which commonly promote them, in practice, by customer surveys and marketing actions aimed at attracting new business through customer referrals. In addition to these customer behaviours, it is also interesting to analyse the clients' information search behaviours on 
the websites. This behaviour may also provide value to the companies, because customers searching for information on the website will be exposed to advertising, which can be a source of income.

An important antecedent of customer behaviour is self-efficacy. This concept was first introduced in Bandura (1977)'s seminal paper, in which the author claimed that the likelihood of people engaging in a particular behaviour depended on their beliefs about their capabilities to undertake the behaviour. Thus, self-efficacy was defined as "people's beliefs in one's capabilities to organise and execute the courses of action required to produce given levels of attainments" (Bandura, 1998; p. 624).

In the specific context of online travel behaviour, online travel self-efficacy has been defined as "consumers' self-assessment of their own capabilities to purchase travel online" (Amaro and Duarte, 2015; p. 67). Some authors have found that self-efficacy is positively associated with online travel purchases (Amaro and Duarte, 2015), and with the use of online travel websites (Joshua and Pujani, 2014). Similarly, efficacy has also been shown to be an important determinant of members' active contributions to an online travel community (Wang and Fesenmaier, 2003), and Lu et al. (2015) found that users with higher levels of self-efficacy in using travel apps tend to have higher expectations of the apps, which results in behavioural intentions to use them.

Personal characteristics and contextual factors may influence the effect of this variable on customer behaviour. Therefore, it is interesting to analyse the role that the generation variable might play in the relationship between self-efficacy and customer engagement behaviours, so we propose the following research question:

RQ2: Does generation effect the influence of self-efficacy on customer engagement behaviours?

Finally, among the numerous antecedents of customer engagement behaviours, probably the most commonly referenced is customer satisfaction (Pansari and Kumar, 2016; van Doorn et al., 2010). The previous literature has provided evidence of the effect of customer satisfaction on purchase and repurchase behaviours, spreading WOM, and giving referrals (Oliver, 1980; Verhoef et al., 2002). In research into customer engagement, Pansari and Kumar (2016) focus on the positive relation between customer satisfaction and purchases. Other customer engagement behaviours can also be considered as consequences or manifestations of customer satisfaction. Highly satisfied customers exhibit more positive engagement behaviours than dissatisfied customers, and thereafter act in ways beneficial to the company (van Doorn et al., 2010). Some studies analyse the mediating and moderating effect of different variables in this relationship, such as personal characteristics, type of product, brand, or firm (Pansari and Kumar, 2016; Verhoef et al., 2002). Van Doorn et al. (2010) proved that, even if the positive effect of satisfaction on customer engagement behaviours is clear, less clear is how factors related to personal characteristics or context can moderate these effects. The generation variable may affect the relationship between satisfaction and customer engagement behaviours; therefore, we pose the following research question:

RQ3: Does generation effect the influence of satisfaction on customer engagement behaviours? 
Figure 1 shows the proposed model underlying this research.

[Insert Figure 1 about here]

\section{Methodology}

The relationships proposed in the research questions were tested using data gathered from customers of social tourism websites. A market research company carried out the fieldwork across eight major Spanish cities, to increase generalisability. The respondents were approached offline and data were collected by means of a personal survey of individuals who had booked a hotel on any social tourism website in the previous 12 months. From a list of popular tourism websites, the respondents had to take the one they had used most recently and give their opinions about it.

Given that there is no standard criterion to establish the exact range of years for each generation, we adopted the most common range from previous studies, which are: 1965 to 1979 for Generation X, 1980 to 1995 for Generation Y, and 1996 to 2000 for Generation $Z$ (as we surveyed only adult members of this generation). The market research company applied non-probabilistic quota sampling by identifying individuals within these generations, until they achieved a target number of respondents ( 350 in total). They also applied a control of veracity on $20 \%$ of the questionnaires and performed new surveys when they detected incomplete or non-reliable returns (e.g., the same answer for all the questions). After excluding four questionnaires because of outlier data, the final sample consisted of 346 individuals. Table 1 shows the profile of the final sample.

\section{[Insert Table 1 about here]}

All the scales were measured by 10-point Likert-type questions. Self-efficacy was measured using two items from Amaro et al. (2016), in the context of online travel. Satisfaction was measured through three items from studies in the hospitality sector (Bravo et al., 2018). Customer engagement were analysed by asking respondents about their intentions to engage in various behaviours. Specifically, scales used in social networks settings were used to measure intentions to make bookings (Kim et al., 2009), to search for information (Banks et al., 2010), and to create content (Banks et al., 2010). A scale taken from Bravo et al. (2018)'s study into the hospitality sector measured intention to spread WOM. Finally, Kumar and Pansari (2016)'s study, conducted across different firms and industries, is the source of the scale to measure intentions to provide feedback and to give referrals. All these scales of intentions used three items, except for intention to book, which relied on two items.

Since completion of the study they have been translated into English and the accuracy of the translation was verified by the research team and an experienced English proof-reader. Moreover, problems of common-method bias were avoided using two statistical procedures. First, the authors verified that the scales were not correlated with a nonrelated question included in the questionnaire. Second, a full collinearity test yielded variance inflation factor (VIF) values lower than 3.3 (Podsakoff et al., 2003). These, and the other analyses in the study, were performed with IBM SPSS Statistics 22.0.

Table 2 shows the items used in the scales and their descriptive statistics.

[Insert Table 2 about here] 


\section{Results}

\subsection{Descriptive analysis}

Before testing the hypotheses, a comparative analysis was performed on the answers given by the different generations. First, self-efficacy, satisfaction, and the six types of engagement behaviours were built as the average of the values the respondents gave to their constituent items. In all cases, Cronbach's alpha values were above 0.7 , which confirmed construct reliability (Nunnally and Bernstein, 1994). Second, the statistical means obtained for each factor and generation were compared through one-way ANOVA tests (see Table 3).

\section{[Insert Table 3 about here]}

As shown in Table 3, customer assessments for each factor were quite homogeneous, regardless of generation, which may be because all the respondents had recent experiences in social tourism websites. Except for intentions to create content $(M=4.46)$ and provide feedback $(\mathrm{M}=6.36)$, all the statistical means were above 7 on a 0 -to-10 scale. According to the results of the ANOVA tests, referrals is the only factor that statistically differs among the generations $(\mathrm{F}$-test $=6.44 ; \mathrm{p}<0.01)$. Scheff post-hoc tests reveal that members of Gen $\mathrm{Z}$ are more willing to give referrals for social tourism websites that those of Gen X $\left(\mathrm{M}_{\mathrm{GZ}}=8.00 ; \mathrm{M}_{\mathrm{GX}}=6.76 ; \mathrm{p}<0.01\right)$ and $\mathrm{Gen} \mathrm{Y}\left(\mathrm{M}_{\mathrm{GZ}}=8.00 ; \mathrm{M}_{\mathrm{GY}}=7.14 ; \mathrm{p}<0.05\right)$. There are no statistical differences for referral intentions between Gen X and Gen Y $\left(\mathrm{M}_{\mathrm{GX}}\right.$ $\left.=6.76 ; \mathrm{M}_{\mathrm{GY}}=7.14 ; \mathrm{p}=0.55\right)$.

\subsection{Regression analyses}

Six hierarchical multiple regressions, one for each type of engagement behaviour, were estimated to test the effects of self-efficacy, satisfaction, and generation on engagement behaviours. The results obtained are shown in Table 4.

The first model considered only self-efficacy and satisfaction as independent variables. A second model added two dummies representing Gen X (1, 0 values) and Gen Y (1, 0 values), Gen $\mathrm{Z}$ being the case where both dummies have 0 values. For example, the final estimated equations for intention to search are:

$$
\begin{aligned}
& \text { SEARCH }_{\mathrm{i}}=\beta_{0}+\beta_{1} \mathrm{SELF}_{\mathrm{i}}+\beta_{2} \mathrm{SAT}_{\mathrm{i}}+\varepsilon_{i}(1) \\
& \mathrm{SEARCH}_{\mathrm{i}}=\beta_{0}+\beta_{1} \mathrm{SELF}_{\mathrm{i}}+\beta_{2} \mathrm{SAT}_{\mathrm{i}}+\beta_{3} \mathrm{GENX}_{\mathrm{i}}+\beta_{4} \mathrm{GENY}_{\mathrm{i}}+\varepsilon_{i}(2),
\end{aligned}
$$

where $\mathrm{i}$ denotes the individual and the variables are intention to search (SEARCH), selfefficacy (SELF), satisfaction (SAT), Gen X (GENX), and Gen Y (GENY). Dummy variables were also added to control the effect of the website.

As expected, the results of the first model show that self-efficacy and satisfaction have positive effects on engagement behaviours towards social tourism websites. For selfefficacy, the results confirm the positive effect of this variable on intentions to search $(\beta$ $=0.28 ; \mathrm{p}<0.01)$, to book $(\beta=0.18 ; \mathrm{p}<0.01)$, to spread WOM $(\beta=0.11 ; \mathrm{p}<0.05)$, to create content $(\beta=0.29 ; \mathrm{p}<0.01)$, and to provide feedback $(\beta=0.23 ; \mathrm{p}<0.01)$, whereas the relationship between self-efficacy and the intention to give referrals is not significant $(\mathrm{p}>0.1)$. 
Satisfaction has the strongest effect on intention to spread WOM $(\beta=0.69 ; \mathrm{p}<0.01)$ and positively influences intentions to search $(\beta=0.39 ; \mathrm{p}<0.01)$, to book $(\beta=0.42 ; \mathrm{p}<0.01)$, to give referrals $(\beta=0.44 ; p<0.01)$ and, to a lesser extent, intentions to provide feedback $(\beta=0.15 ; p<0.05)$ and to create content $(\beta=0.12 ; \mathrm{p}<0.1)$.

The estimates from Model 2 indicate that the inclusion of generation is an improvement on the first model in the case of intention to search $(\mathrm{F}-\mathrm{var} .=3.58 ; \mathrm{p}<0.05)$, to book $(\mathrm{F}-$ var.=2.73; $\mathrm{p}<0.1)$, and to give referrals $(\mathrm{F}-\mathrm{var} .=5.68 ; \mathrm{p}<0.01)$. These results show that generation may influence customer engagement behaviours towards social tourism websites, which gives RQ1 an affirmative answer.

A closer look at the data shows that both Gen $\mathrm{X}$ and Gen $\mathrm{Y}$ have a significant influence on intention to search $\left(\beta_{X}=0.12 ; \beta_{Y}=0.10 ; t_{X}=2.52 ; t_{Y}=2.08\right)$, to book $\left(\beta_{X}=0.09 ; \beta_{Y}=\right.$ $\left.0.10 ; t_{X}=1.93 ; t_{Y}=2.13\right)$, and to give referrals $\left(\beta_{X}=-0.19 ; \beta_{Y}=-0.13 ; t_{X}=-3.29 ; t_{Y}=-\right.$ 2.32). These results mean that Gen Z's behavioural intentions differ from the others, as they are more likely to give referrals but less likely to search for information and to book hotels in a specific social tourism website.

Gen X might be more willing, in comparison to the other generations, to provide feedback to the website company, since this variable exerted a positive and significant effect at $95 \%$ confidence level $\left(\beta_{\mathrm{X}}=0.12 ; \beta_{\mathrm{Y}}=0.09 ; \mathrm{t}_{\mathrm{X}}=2.05 ; \mathrm{t}_{\mathrm{Y}}=1.55\right)$. However, the effect was not strong enough to improve the first model $(\mathrm{F}-\mathrm{var} .=2.26 ; \mathrm{p}=0.11)$.

[Insert Table 4 about here]

To estimate the interaction or moderating effects between the variables, six new hierarchical regressions were estimated, in which we compared the second model against a third model that included all the interaction terms. For example, in the case of intention to search, the new model is:

SEARCH $_{\mathrm{i}}=\beta_{0}+\beta_{1} \mathrm{SELF}_{\mathrm{i}}+\beta_{2} \mathrm{SAT}_{\mathrm{i}}+\beta_{3} \mathrm{GENX}_{\mathrm{i}}+\beta_{4} \mathrm{GENY}_{\mathrm{i}}+\beta_{5} \mathrm{SELF}_{i} \mathrm{SAT}_{\mathrm{i}}+$ $\beta_{6}$ SELF $_{i}$ GENX $_{i}+\beta_{7}$ SELF $_{i}$ GENY $_{i}+\beta_{8}$ SAT $_{i}$ GENX $_{\mathrm{i}}+\beta_{9}$ SAT $_{i} \mathrm{GENY}_{\mathrm{i}}+$ $\beta_{10} \mathrm{SELF}_{i} \mathrm{SAT}_{i} \mathrm{GENX}_{i}+\beta_{11} \mathrm{SELF}_{i} \mathrm{SAT}_{i} \mathrm{GENY}_{i}+\varepsilon_{i}(3)$,

where $\mathrm{i}$ denotes the individual and the variables are intention to search (SEARCH), selfefficacy (SELF), satisfaction (SAT), Gen X (GENX), and Gen Y (GENY). Dummy variables were also added to control the effect of the website.

As the inclusion of interaction terms caused severe multicollinearity problems, the estimations were repeated using mean-centred variables for the interaction terms. This approach, which involves building new variables by subtracting the original variable from its average, is an effective way of reducing correlation between variables (Aiken and West, 1991). The results obtained are shown in Table 5.

[Insert Table 5 about here]

In accordance with RQ2 and RQ3, the third model only improves on the previous models for the variable intention to spread WOM (F-var.= 2.23; $\mathrm{p}<0.05)$. Specifically, selfefficacy shows a higher effect on intention to spread WOM for Gen X than for the other generations $(\beta=0.19 ; p<0.01)$ whereas the effect of satisfaction on WOM is the opposite $(\beta=-0.16 ; \mathrm{p}<0.05)$. Moreover, regardless of the F-variation between the models, this 
analysis reveals other interesting patterns that affect some of these direct effects reported above. Compared to the other generations, in Gen $\mathrm{X}$ satisfaction is less related to intention to create content $(\beta=-0.19 ; \mathrm{p}<0.1)$, and has a coefficient close to zero for intention to search and to book. In Gen Y, satisfaction shows a stronger influence on intention to search $(\beta=0.13 ; \mathrm{p}<0.1)$ and to book $(\beta=0.15 ; \mathrm{p}<0.05)$.

The existence of moderating effects suggests that the effects of Gen Y on intention to search and of Gen X on intention to book are weakened to the point that they are no longer significant ( $p>0.1$ ). Intention to give referrals is also not related to Gen Y in Model 3, although no moderating effects were found in this case. Hence, these results suggest that the main variable that distinguishes Gen $\mathrm{Z}$ from the other generations is intention to give referrals, not search or booking behaviours.

\section{Conclusions}

\subsection{Discussion}

In line with previous research, this paper confirms that individuals from different generations have different behaviours in online settings (Amaro et al., 2016). However, by taking a step further than previous literature, our study shows that differences across generations arise even when all the respondents are online customers.

The results suggest that Gen $\mathrm{Z}$ is the most differentiated generation. In particular, future intentions to search for information and to book on the same social tourism website are higher for Gen X and Y than for Gen Z. Gen X is also more willing to provide feedback to the website. This can be explained because Gen $\mathrm{X}$ and $\mathrm{Y}$ value loyalty more (Pendergast, 2009), whereas members of Gen $\mathrm{Z}$ are not afraid of continuous change and have no sense of commitment (Bencsik et al., 2016). On the contrary, it was found that Gen $\mathrm{Z}$ is more likely to give referrals than Gen $\mathrm{X}$ and Gen Y. This is consistent with the notion that members of Gen $Z$ engage more on social networking sites and have a broader range of friends on these sites to whom to send referrals. As a result of having grown up in the age of social media, they are more familiar with these types of promotional activities (Berkup, 2014; Skinner, 2018) and, therefore, are more willing to use them.

Regarding interaction effects, self-efficacy exerted higher effects on intention to spread WOM for Gen X. Members of Gen X need to feel confident about their skills in using the website in order to spread WOM. The reason behind this result may be that younger generations are more tech-savvy (Bennet et al., 2008). In addition, members of Gen X have used traditional travel agencies more. Therefore, social tourism websites have more novelty for them than for Gen Y and Gen Z. In consequence, they need to be sure that they know how to use the website before recommending it to others. On the contrary, evidence was found, for Gen X, that satisfaction with the social tourism website had lower effects on intention to spread WOM and intention to create content. This means that, even if members of Gen X are satisfied with the site, they are less prone to spread WOM and to create content than younger generations, as the latter are more active on social networking sites (Berkup, 2014).

Moreover, the results reflect that, for Gen Y, satisfaction with the social tourism website exerted higher effects on intention to search for information and book a room through the site. As these are signs of loyalty to the site, we can infer that satisfaction is a more important driver for remaining loyal to a website for members of Gen Y than for members 
of the other generations. Therefore, only when members of Gen Y are satisfied will they be loyal to the social tourism website. This is consistent with the idea that members of this generation are investigative and well-informed (Tapscott, 1998; Chiopu et al., 2016) and value loyalty (Pendergast, 2009).

\subsection{Theoretical implications}

This study offers a number of theoretical contributions to academic research. First of all, existing studies using generational analysis to understand customer behaviours in tourism have mostly compared the travel behaviours of the Silent Generation, Baby Boomers, Generation X and Generation Y (Beldona, 2005; Li et al., 2013; Gardiner et al., 2014; Luna-Cortés et al., 2018). However, Generation $\mathrm{Z}$ has received limited attention in the literature. This study fills this gap by empirically analysing the intergenerational differences between Generation X, Generation Y, and Generation Z in the specific context of social tourism websites.

Second, most research drawing on generational cohort theory to understand tourists' behaviours has mainly focused on a limited set of variables, destination preferences ( $\mathrm{Li}$ et al., 2013; Huang and Lu, 2017), information search (Beldona, 2005; Li et al., 2013; Huang and $\mathrm{Lu}, 2017$ ) and motivations for travelling (Huang and $\mathrm{Lu}, 2017$ ). In the specific context of tourism websites, the scope has been even narrower, with most of the research limited to the analysis of the use of other travellers' content and the creation of online reviews (Amaro et al. 2016; TripAdvisor, 2016). Therefore, this study advances knowledge by empirically analysing both transactional and non-transactional customer engagement behaviours on social tourism websites. In particular, it contributes to the understanding of different actions, such as searching for information, booking, spreading WOM, creating content, providing feedback and giving referrals, which are of high importance on social tourism websites. In addition, this study advances previous research by testing the direct effect of generations on customer engagement behaviours and their interaction effects with satisfaction with the site and perceived self-efficacy in using the site.

\subsection{Managerial implications}

As in other sectors, satisfaction is a requirement for positive customer responses towards social tourism websites. For all the generations, self-efficacy is also an important requisite for customers to engage with online platforms. Consequently, it is crucial for social tourism websites to promote these activities and make the sites easy to use.

The results obtained indicate that the three generations may be attractive for tourism websites. Gen $X$ are more willing to search and provide feedback to the same webpage. Gen $\mathrm{Y}$ is more likely to re-book on the same platform and Gen $\mathrm{Z}$ is more prone to give referrals. The key is how to retain these different profiles and turn them into loyal customers, which may be more challenging with Gen Z. Members of Gen X are usually loyal customers, Gen Y will be loyal depending on whether they are satisfied with the website, and Gen $\mathrm{Z}$ will readily shift their choices regardless of previous experiences.

The first step for social tourism websites should be to classify their visitors by means of online technologies (e.g., cookies) or direct questions. For example, a question about year 
of birth is common for accessing for a first time those websites appropriate only for consumers of legal age. Besides controlling users' ages for privacy and legal reasons, social tourism websites could benefit from this information by categorising individuals according to generation. When they have allocated website visitors to a specific generation, tourism websites might be able to offer customised content to lead these visitors towards desired behaviours.

The results of the present study show that the customer's perception of self-efficacy is more important for members of Gen $\mathrm{X}$ than for other generations as a motivator to spread WOM. As this generation is relatively less tech savvy and more loyal than younger generations, it is particularly important that managers of social tourism websites pay special attention to aspects such as ease of use. When searching for a hotel, the webpage's results list should not be overwhelmingly aimed at these individuals and prioritise only those hotels or destinations where they have previously stayed. Moreover, their purchasing processes might be simplified by including "expanding views" menus, which would "hide" those options less likely to be selected.

Unlike Gen X, we can expect that members of Gen $\mathrm{Z}$ are more open to novelty and social interactions and are not afraid of technology and information overload. They may be more attracted by discounts in subsequent purchases and rewards, and by social networks where they can access and share content with their peers. Websites could be made more appealing for Gen Z by introducing game elements (e.g., points and medals) (Skinner et al., 2018).

Satisfaction is the key for attracting Gen Y. This group is also tech-savvy and wellinformed, and their intentions to search for and to book a hotel are contingent on their previous satisfaction. Hence, it is crucial for tourism companies to examine the customer journey of these individuals in depth, and pinpoint those moments that might affect their satisfaction. A start point may be to monitor website metrics, such as conversion rates, bounce rates of specific pages (e.g., pages about payment) and interactions with specific contents (likes, comments, etc.), across the generations.

\subsection{Limitations and future research lines}

In order to generalize the results, future research should replicate this study in countries other than Spain and collect longitudinal data to examine the interactions between the examined variables over time. Second, this study focuses on the three youngest generations of consumers (Generation X, Generation Y, and Generation Z). Although these are the heaviest users of social tourism websites, it would be interesting for future research also to include older generations (i.e., Baby Boomers) to better understand generational differences in customer engagement behaviours. The specific role of psychological variables and sociodemographic variables underlying each generation could also be examined to discover whether generation better explains customer behaviour than these individual variables. Even where intergenerational differences are not the main focus of further customer engagement studies, generational effects should be considered, at least as a control variable.

\section{References}


Aiken, L. S., \& West, S. G. (1991). Multiple regression: Testing and interpreting interactions. Newbury Park, CA: Sage.

Amaro, S. \& Duarte, P. (2015). An integrative model of consumers' intentions to purchase travel online. Tourism Management, 46, 64-79. https://doi.org/10.1016/j.tourman.2014.06.006

Amaro, S., Henriques, C., \& Duarte, P. (2016). Comparing millennials with their predecessors regarding online travel behaviours: A logistical regression modelling approach. In Proceedings of the 15th European Conference on Research Methodology for Business Management, Kingston Business School, United Kingdom.

Bandura, A. (1977). Self-efficacy: Toward a unifying theory of behavioral change. Psychology Review, 84(2), 191-215. http://dx.doi.org/10.1037/0033-295X.84.2.191

Bandura, A. (1998). Health promotion from the perspective of social cognitive theory. Psychology and Health, 13, 623-649. https://doi.org/10.1080/08870449808407422

Banks, M.S., Onita, C., \& Meservy, T. (2010). Risky behaviour in online social media: Protection motivation and social influence. In Proceedings of the Sixteenth Conference on Information Systems, Lima, Peru.

Beldona, S. (2005). Cohort analysis of online travel information search behavior: 19952000. Journal of Travel Research, 44, 135-142. https://doi.org/10.1177/0047287505278995

Beldona, S., Nusair, K., \& Demicco, F. (2009). Online travel purchase behavior of generational cohorts: A longitudinal study. Journal of Hospitality Marketing \& Management, 18, 406-420. https://doi.org/10.1080/19368620902799627

Bencsik, A., Horváth-Csikós, G., \& Juhász, T. (2016). Y and Z Generations at Workplaces. Journal of Competitiveness, 8(3). https://doi.org/10.7441/joc.2016.03.06

Berkup, S. (2014). Working with Generations $\mathrm{X}$ and $\mathrm{Y}$ in Generation $\mathrm{Z}$ period: Management of different generations in business life. Mediterranean Journal of Social Sciences, 5, 218-229. https://doi.org/10.5901/mjss.2014.v5n19p218

Bravo, R., Martínez, E., \& Pina, J.M. (2018). Effects of service experience on customer responses to a hotel chain. International Journal of Contemporary Hospitality Management, 30 (11). https://doi.org/10.1108/IJCHM-09-2017-0569

Casaló, L.V., Guinalíu, M., \& Flavián, C. (2010). Determinants of the intention to participate in firm-hosted online travel communities and effects on consumer behavioral intentions. Tourism Management, 31, 898-911. https://doi.org/10.1016/j.tourman.2010.04.007

Chiopu, A., Padurean, A., Alà, M. \& Nica, A. (2016). The influence of new technologies on tourism consumption behavior of the Millennials. Amfiteatru Economic Journal, 18(10), 829-846.

Cheung, S. \& Chan, K. (2000). The role of perceived behavioral control in predicting human behaviour: A meta-analytic review of studies on the Theory of Planned Behavior. Unpublished manuscript. Chinese University of Hong Kong.

Chung, J., Chen, C., Lin, Y. (2016). Cross-strait tourism and generational cohorts. Journal of Travel Research, 55, 813-826. https://doi.org/10.1177/0047287515569775 
Davis, F.D., Bagozzi, R.P., \& Warshaw, P.R. (1989). User acceptance of computer technology: a comparison of two theoretical models. Management Science, 35 (8), 9821003. https://doi.org/10.1287/mnsc.35.8.98

Eastin, M. \& La Rose, R. (2000). Internet self-efficacy and the psychology of the digital divide. Journal of Computer-Mediated Communication, 6(1). https://doi.org/10.1111/j.1083-6101.2000.tb00110.x

EY (2015). What if the next big disruptor isn't a what but a who? https://www.ey.com/Publication/vwLUAssets/EY-rise-of-gen-znew-challenge-forretailers/\%24FILE/EY-rise-of-gen-znew-challenge-for-retailers.pdf

French, A.M., Luo, X., \& Bose, R. (2017). Toward a holistic understanding of continued use of social networking tourism: A mixed-methods approach, Information and Management, 54(6), 802-813. https://doi.org/10.1016/j.im.2016.10.006

Gardiner, S., Grace, D., \& King, C. (2014). The generation effect: The future of domestic tourism in Australia. Journal of Travel Research, 53, 705-720. https://doi.org/10.1177/0047287514530810

Gretzel, U. \& Yoo, K. (2008). Use and impact of online travel reviews. In Proceedings of the ENTER 2008 International Conference, Innsbruck, Austria. https://doi.org/10.1007/978-3-211-77280-5_4

Herrando, C., Jimenez-Martinez, J. \& Martin-De Hoyos, M.J. /2019). Tell me your age and I tell you what you trust: the moderating effect of generations. Internet Research. https://doi.org/10.1108/IntR-03-2017-0135

Hollebeek, L. (2011). Exploring customer brand engagement: definition and themes. Journal of Strategic Marketing, 19(7), 555-573. https://doi.org/10.1080/0965254X.2011.599493

Huang, Q. \& Lu, Y. (2017). Generational perspective on consumer behaviour: China's potential outbound tourist market. Tourism Management Perspectives, 24, 7-15. https://doi.org/10.1016/j.tmp.2017.07.008

Inglehart, R. (1977). The Silent Revolution. Changing Values and Political Styles among Western Publics. Princeton, NJ: Princeton UniversityPress. Retrieved from http://www.jstor.org/stable/j.ctt13x18ck

Islam, J.U. \& Rahman, Z. (2016). The transpiring journey of customer engagement research in marketing. A systematic review of the past decade. Management Decision, 54(8), 2008-2034. https://doi.org/10.1108/MD-01-2016-0028

Joshua, N \& Pujani, V. (2014). Customer satisfaction in using e-travel: The role of selfefficacy, trust and use. International Journal of Trade and Finance, 5, 459-462. https://doi.org/10.7763/IJTEF.2014.V5.416

Kim, H., Kim, T., \& Shin, S. (2009). Modeling roles of subjective norms and eTrust in customers' acceptance of airline B2C eCommerce websites. Tourism Management, 30, 266-277. https://doi.org/10.1016/j.tourman.2008.07.001

Krishen, A. S., Berezan, O., Agarwal, S., \& Kachroo, P. (2016). The generation of virtual needs: Recipes for satisfaction in social media networking. Journal of Business Research, 69(11), 5248-5254. https://doi.org/10.1016/j.jbusres.2016.04.120 
Kumar, V., \& Pansari, A. (2016). Competitive advantage through engagement. Journal of Marketing Research, 53(4), 497-514. https://doi.org/10.1509/jmr.15.0044

Li, C., Cui, G., \& Peng, L. (2017). The signaling effect of management response in engaging customers: A study of the hotel industry. Tourism Management, 62, 42-53. https://doi.org/10.1016/j.tourman.2017.03.009

Li, X., Li, X., \& Hudson, S. (2013). The application of generational theory to tourism consumer behaviour: An American perspective. Tourism Management, 37, 147-164. https://doi.org/10.1016/j.tourman.2013.01.015

Lissitsa, S. \& Kol, O. (2016). Generation X vs. Generation Y - A decade of online shopping. Journal of Retailing and Consumer Services 31, 304-312. http://dx.doi.org/10.1016/j.jretconser.2016.04.015

Lu, J., Mao, Z., Wang, M., \& Hu, L. (2015). Goodbye maps, hello aps? Exploring the influential determinants of travel app adoption. Current Issues in Tourism, 18 (11), 10591079. https://doi.org/10.1080/13683500.2015.1043248

Luna-Cortés, G. (2018). Differences among generations of USA tourists regarding the positive content created about Colombia in social media. Journal of Hospitality and Tourism Management, 36, 31-39. https://doi.org/10.1016/j.jhtm.2018.07.002

Maital, S. (2014). Can Generation Y save Israel and the world?. The Jerusalem Report, issue Jan 13, 2014, 34. https://www.jpost.com/Jerusalem-Report/Israel/Can-GenerationY-save-Israel-336190.

Mangold, W. \& Smith, K. (2012). Selling to Millennials with online reviews. Business Horizons, 55(2), 141-153. https://doi.org/10.1016/j.bushor.2011.11.001

Mannheim, K. (1952). The Problem of Generations. In P. Kecskemeti (Ed.), Essays on the Sociology of Knowledge (276-320). London: Routledge and Kegan Paul.

Marjanen, H., Kohijoki, A., Saastamoinen, K., \& Engblom, J. (2019). Old dogs learnig new tricks? The effect of age and generation on shopping behaviour. Proceedings of the $20^{\text {th }}$ Conference of the European Association for Education and Research in Commercial Distribution.

Martínez-González, J., Parra-López, E., \& Buhalis, D. (2017). The loyalty of young residents in an island destination: An integrated model. Journal of Destination Marketing \& Management, 6(4), 444-455. https://doi.org/10.1016/j.jdmm.2016.07.003

Munar, A.M. \& Jacobsen, J.K.S. (2014). Motivations for sharing tourism experiences through social media, Tourism Management, 43, 46-54. https://doi.org/10.1016/j.tourman.2014.01.012

Nichols, T., \& Wright, M. (2018). Generational differences: Understanding and exploring Generation Z. In Southwest Academy of Management Proceedings Annual Meeting, Albuquerque, 177-185.

Nunnally, A., \& Bernstein, I. (1994). Psychometric theory. McGraw-Hill.

Oliver, R.L. (1980). A cognitive model of the antecedents and consequences of satisfaction decisions. Journal of Marketing Research, 460-469. https://doi.org/10.2307/3150499 
Pansari, A. \& Kumar, V. (2016). Customer engagement: the construct, antecedents and consequences. Journal of the Academy of the Marketing Science, 45(3), 294-311. https://doi.org/10.1007/s11747-016-0485-6

Podsakoff, P.M., MacKenzie, S.B., Lee, J.Y. \& Podsakoff, N.P. (2003). Common method biases in behavioral research: a critical review of the literature and recommended remedies. Journal of Applied Psychology, 88, 879-903. https://doi.org/10.1037/00219010.88.5.879

Priporas, C., Stylos, N., \& Fotiadis, A. (2017). Generation Z consumers' expectations of interactions in smart retailing: A future agenda. Computers in Human Behavior, 77, 374381. https://doi.org/10.1016/j.chb.2017.01.058

Skinner, H., Sarpong, D., \& White, G. R. (2018). Meeting the needs of the Millennials and Generation Z: gamification in tourism through geocaching. Journal of Tourism Futures, 4(1), 93-104. https://doi.org/10.1108/JTF-12-2017-0060

Smola, K. \& Sutton, C. (2002). Generational differences: Revisiting generational work values for New Millennium. Journal of Organizational Behavior, 23(4), 363-382. https://doi.org/10.1002/job.147

Strauss, W. \& Howe, N. (1997). The Fourth Turning: An American Prophecy - What the Cycles of History Tell Us About America's Next Rendezvous with Destiny. Broadway Books.

Taylor, M.K. (2018). Xennials: a Microgeneration in the Workplace. Industrial and Commercial Training, 50(3), 136-147. https://doi:10.1108/ICT-08-2017-0065

Time (2013). Millennials: The Me Me Me Generation. https://time.com/247/millennialsthe-me-me-me-generation/

Tripadvisor. (2015). 6 key travel trends for 2016. https://www.tripadvisor.com/TripAdvisorInsights/w665

TripAdvisor (2016). TripBarometer 2016. Traveler Trends \& Motivations. Global Findings.

van den Bergh, J. \& Behrer, M. (2013), How Cool Brands Stay Hot: Branding to Generation Y. Kogan Page, London.

Van Doorn, J., Lemon, K.N., Mittal, V., Nass, S., Pick, D., Pirner, P., \& Verhoef, P.C. (2010). Customer engagement behavior: theoretical foundations and research directions. Journal of Service Research, 13(3), 253-266. https://doi.org/10.1177/1094670510375599

Verhoef, P.C., Franses, P.H., \& Hoekstra, J.C. (2002). The Effect of Relational Constructs on Customer Referrals and Number of Services Purchased From a Multiservice Provider: Does Age of Relationship Matter? Journal of the Academy of Marketing Science, 30 (3), 202-216. https://doi.org/10.1177/00970302030003002, hdl.handle.net/1765/58828

Verhoef, P. C., Reinartz, W. J., \& Krafft, M. (2010). Customer engagement as a new perspective in customer management. Journal of Service Research, 13(3), 247-252. https://doi.org/10.1177/1094670510375461

Vijayasarathy, L. (2004). Predicting consumer intentions to use on-line shopping: The case for Augmented Technology Acceptance Model. Information \& Management, 41, 747-762. http://dx.doi.org/10.1016/j.im.2003.08.011 
Wang, Y. \& Fesenmaier, D.R. (2003). Assessing motivation of contribution in online communities: An empirical investigation of an online travel community. Electronic Markets, 13 (1), 33-45. http://dx.doi.org/10.1080/1019678032000052934

Wang, X., Li, X., Li, Q., \& Peng, L. (2014). Intention of Sharing Travel Experiences on Social Media: Motivations and the Moderating Effects of Face Orientation. In Proceedings of the 25th Australasian Conference on Information Systems, Auckland, New Zealand. http://hdl.handle.net/10292/8068

Wang, J., Wang, S., Xue, H., Wang, Y., \& Li, J. (2018). Green image and consumers' word-of-mouth intention in the green hotel industry: The moderating effect of Millennials. Journal of Cleaner Production, 181, 426-436. https://doi.org/10.1016/j.jclepro.2018.01.250

Wei, W., Miao, L., \& Huang, Z. (2013). Customer engagement behaviors and hotel responses. International Journal of Hospitality Management, 33, 316-330. https://doi.org/10.1016/j.ijhm.2012.10.002

Wiedmer, T. (2015). Generations do differ: Best practices in leading Traditionalists, Boomers, and Generations X, Y, and Z. Delta Kappa Gamma Bulletin, 82(1), 51-58.

Wu, I.L., \& Chen, J.L. (2005). An extension of trust and TAM model with TPB in the initial adoption of on-line tax: an empirical study. International Journal of HumanComputer Studies, 62, 784-808. https://doi.org/10.1016/j.ijhcs.2005.03.003

Xiang, Z., Magnini, V. \& Fesenmaier, D. (2015). Information technology and consumer behavior in travel and tourism: Insights from travel planning using the internet. Journal of Retailing and Consumer Services, 22, 244-249. https://doi.org/10.1016/j.jretconser.2014.08.005

Zopiatis, A., Krambia-Kapardis, M., \& Varnavas, A. (2012). Y-ers, X-ers and Boomers: Investigating the multigenerational (mis) perceptions in the hospitality workplace. Tourism and Hospitality Research, 12(2), 101-121. https://doi.org/10.1177/1467358412466668

Zhang, H., Wang, P.J.J., \& Chen, X. (2017). A novel decision support model for satisfactory restaurants utilizing social information: A case study of TripAdvisor.com, Tourism Management, 59, 281-297. https://doi.org/10.1016/j.tourman.2016.08.010 
Figure 1. Proposed model

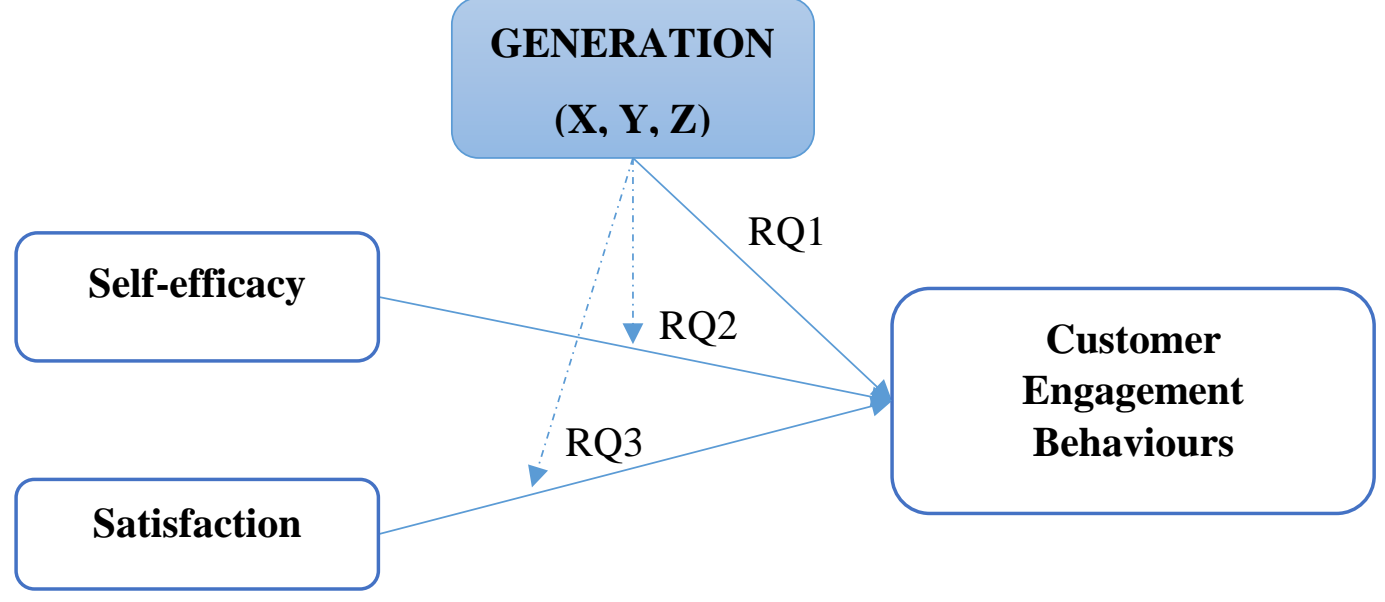


Table 1. Sample composition

\begin{tabular}{llll}
\hline Profile category & & Frequency & Percentage (\%) \\
\hline Generation & Gen X (1965-1979) & 115 & 33.2 \\
& Gen Y (1980-1995) & 117 & 33.8 \\
& Gen Z (1996-2000) & 114 & 33.0 \\
\hline Gender & Women & 212 & 61.3 \\
& Men & 134 & 38.7 \\
\hline Social tourism website & Booking & 196 & 56.6 \\
& Trivago & 61 & 17.6 \\
& Kayak & 32 & 9.2 \\
& TripAdvisor & 25 & 7.2 \\
& Hoteles.com & 15 & 4.3 \\
& Expedia & 12 & 3.5 \\
& Atrapalo & 2 & 0.6 \\
& Centraldereservas.com & 1 & 0.3 \\
& Lastminute & 1 & 0.3 \\
\hline Experience in creating & Yes & 110 & 31.8 \\
content in the website & No & 236 & 68.2 \\
\hline Receive rewards for & Yes & 38 & 11.0 \\
creating content & No & 308 & 89.0 \\
\hline
\end{tabular}


Table 2. Composition of the scales

\begin{tabular}{|c|c|c|c|c|}
\hline Scales & Mean & SD & Skew & Kurtosis \\
\hline \multicolumn{5}{|l|}{ Self-efficacy (Amaro et al., 2010) } \\
\hline SELF1. I am proficient in using the Internet for booking hotels & 6.96 & 2.13 & -0.63 & 0.03 \\
\hline SELF2. I feel confident that I can use the Internet to book hotels & 7.29 & 1.99 & -0.83 & 0.53 \\
\hline \multicolumn{5}{|l|}{ Satisfaction (Ali et al. 2016; Bravo et al., 2018) } \\
\hline SAT1. I am satisfied with my decision to have booked through X & 7.66 & 1.67 & -0.82 & 0.48 \\
\hline SAT2. My choice to book through X was a wise one & 7.68 & 1.68 & -0.72 & 0.30 \\
\hline SAT3. I think I did the right thing when I chose $X$ & 7.60 & 1.71 & -0.72 & 0.27 \\
\hline \multicolumn{5}{|l|}{ Intention to search for information (Banks et al., 2010) } \\
\hline SEARCH1. I intend to search for information on X for my next trip & 7.62 & 1.86 & -1.04 & 1.51 \\
\hline SEARCH2. In the future, I would like to read comments about hotels on X & 7.40 & 2.13 & -1.04 & 1.47 \\
\hline SEARCH3. In my next trip, I plan to consult reviews of the hotels on $\mathrm{X}$ & 7.63 & 1.89 & -0.87 & 1.13 \\
\hline \multicolumn{5}{|l|}{ Intention to book (Kim et al., 2009) } \\
\hline BOOK1. When I need to book a hotel, I will use $\mathrm{X}$ as my first option & 6.91 & 2.25 & -0.52 & -0.17 \\
\hline BOOK2. I am likely to book hotels through X & 7.45 & 1.81 & -0.75 & 0.80 \\
\hline \multicolumn{5}{|l|}{ Intention to spread WOM (Bravo et al., 2018) } \\
\hline WOM1. I am likely to say good things about X & 7.59 & 1.81 & -1.05 & 1.63 \\
\hline WOM2. I would recommend X to my family & 7.56 & 1.92 & -1.07 & 1.41 \\
\hline WOM3. If my friends were looking for a hotel, I would tell them to use $\mathrm{X}$ & 7.48 & 1.93 & -0.92 & 0.79 \\
\hline \multicolumn{5}{|l|}{ Intention to create content (Banks et al., 2010) } \\
\hline $\begin{array}{l}\text { CREATE1. I intend to share information on } \mathrm{X} \text { about my experiences in } \\
\text { hotels }\end{array}$ & 4.43 & 2.98 & -0.11 & -1.17 \\
\hline $\begin{array}{l}\text { CREATE2. In the future, I would like to write comments or upload photos } \\
\text { about my next trip }\end{array}$ & 3.88 & 3.07 & 0.14 & -1.26 \\
\hline CREATE3. In my next trip, I would like to review the hotels I book & 5.07 & 2.95 & -0.30 & -1.03 \\
\hline \multicolumn{5}{|l|}{ Intention to provide feedback (Kumar and Pansari, 2016) } \\
\hline FEEDBACK1. I would provide feedback to $\mathrm{X}$ about my experiences & 4.32 & 3.05 & -0.03 & -1.26 \\
\hline $\begin{array}{l}\text { FEEDBACK2. I would provide suggestions to X about their current } \\
\text { services }\end{array}$ & 4.49 & 2.87 & -0.05 & -1.00 \\
\hline $\begin{array}{l}\text { FEEDBACK3. I would provide suggestions to X for developing new } \\
\text { services }\end{array}$ & 4.25 & 2.95 & 0.02 & -1.14 \\
\hline \multicolumn{5}{|l|}{ Intention to give referrals (Kumar and Pansari, 2016) } \\
\hline $\begin{array}{l}\text { REFERRAL1. I would invite others to use } \mathrm{X} \text { if I receive referral benefits } \\
\text { (points, money, discounts) for it }\end{array}$ & 7.19 & 2.91 & -0.99 & 0.02 \\
\hline $\begin{array}{l}\text { REFERRAL2. I would encourage other people to use X not only for its } \\
\text { value, but for the referral incentives }\end{array}$ & 7.00 & 2.88 & -0.96 & -0.01 \\
\hline $\begin{array}{l}\text { REFERRAL3. I would like to obtain referral incentives to invite friends } \\
\text { and family to use X }\end{array}$ & 7.69 & 2.77 & -1.27 & 0.78 \\
\hline
\end{tabular}

Note: $\mathrm{X}$ refers to the specific tourism website indicated by each respondent. 
Table 3. Descriptive analysis and ANOVA results

\begin{tabular}{lccccc}
\hline & $\begin{array}{c}\text { Gen X } \\
(\text { mean) }\end{array}$ & $\begin{array}{c}\text { Gen Y } \\
(\text { mean })\end{array}$ & $\begin{array}{c}\text { Gen Z } \\
(\text { mean) }\end{array}$ & $\begin{array}{c}\text { Total } \\
\text { (mean) }\end{array}$ & F-test \\
\hline Self-efficacy & 6.98 & 7.15 & 7.23 & 7.12 & 0.551 \\
Satisfaction & 7.55 & 7.65 & 7.74 & 7.65 & 0.401 \\
Search & 7.65 & 7.70 & 7.31 & 7.55 & 1.708 \\
Book & 7.24 & 7.41 & 6.90 & 7.18 & 2.121 \\
WOM & 7.35 & 7.65 & 7.64 & 7.55 & 1.076 \\
Content & 4.55 & 4.57 & 4.27 & 4.46 & 0.424 \\
Feedback & 4.55 & 4.45 & 4.06 & 4.36 & 1.041 \\
Referrals & 6.76 & 7.14 & 8.00 & 7.30 & $6.444 * * *$ \\
\hline
\end{tabular}

$* * * p \leq 0.001$ 
Table 4. Results of regressions

\begin{tabular}{|c|c|c|c|c|c|c|c|c|c|c|c|c|c|}
\hline \multicolumn{2}{|l|}{$(\mathrm{N}=346)$} & \multicolumn{2}{|c|}{ SEARCH } & \multicolumn{2}{|l|}{ BOOK } & \multicolumn{2}{|l|}{ WOM } & \multicolumn{2}{|c|}{ CONTENT } & \multicolumn{2}{|c|}{ FEEDBACK } & \multicolumn{2}{|c|}{ REFERRALS } \\
\hline & & $\beta$ (St.) & t-value & $\beta$ (St.) & t-value & $\beta$ (St.) & t-value & $\beta$ (St.) & t-value & $\beta$ (St.) & t-value & $\beta$ (St.) & t-value \\
\hline Model 1 & Constant & & $5.012 * * *$ & & $4.073 * * *$ & & $1.695^{*}$ & & -0.003 & & 0.188 & & $2.160 * *$ \\
\hline \multirow[t]{2}{*}{ (M1) } & SELF & 0.282 & $5.528 * * *$ & 0.184 & $3.522 * * *$ & 0.108 & $2.425^{* *}$ & 0.292 & $4.462 * * *$ & 0.233 & $3.521 * * *$ & 0.024 & 0.376 \\
\hline & SAT & 0.386 & $7.454 * * *$ & 0.421 & $7.949 * * *$ & 0.685 & $15.194 * * *$ & 0.119 & $1.794 *$ & 0.149 & $2.210 * *$ & 0.443 & $6.918 * * *$ \\
\hline \multirow{5}{*}{$\begin{array}{l}\text { Model } 2 \\
(\mathrm{M} 2)\end{array}$} & Constant & & $3.867 * * *$ & & $3.081 * * *$ & & $1.695^{*}$ & & -0.544 & & -0.522 & & $3.158 * * *$ \\
\hline & SELF & 0.288 & $5.690 * * *$ & 0.189 & $3.634 * * *$ & 0.106 & $2.380 * *$ & 0.297 & $4.536 * * *$ & 0.240 & $3.633 * * *$ & 0.013 & 0.216 \\
\hline & SAT & 0.394 & $7.653 * * *$ & 0.428 & $8.112 * * *$ & 0.684 & $15.153 * * *$ & 0.126 & $1.887 *$ & 0.157 & $2.336^{* *}$ & 0.431 & $6.812 * * *$ \\
\hline & GENX & 0.116 & $2.518 * *$ & 0.091 & $1.927 *$ & -0.035 & -0.867 & 0.089 & 1.488 & 0.123 & $2.053 * *$ & -0.186 & $-3.293 * * *$ \\
\hline & GENY & 0.096 & $2.081 * *$ & 0.101 & $2.131 * *$ & 0.019 & 0.473 & 0.078 & 1.311 & 0.093 & 1.547 & -0.132 & $-2.323 * *$ \\
\hline \multicolumn{2}{|c|}{ M1-Adjusted R2 } & \multicolumn{2}{|l|}{0.466} & \multicolumn{2}{|l|}{0.440} & \multicolumn{2}{|l|}{0.595} & \multicolumn{2}{|l|}{0.117} & \multicolumn{2}{|l|}{0.096} & \multicolumn{2}{|l|}{0.182} \\
\hline \multicolumn{2}{|c|}{ M2-Adjusted R2 } & \multicolumn{2}{|l|}{0.474} & \multicolumn{2}{|l|}{0.446} & \multicolumn{2}{|l|}{0.594} & \multicolumn{2}{|l|}{0.119} & \multicolumn{2}{|l|}{0.103} & \multicolumn{2}{|l|}{0.203} \\
\hline \multicolumn{2}{|c|}{ M1-F (Sig.) } & \multicolumn{2}{|c|}{$51.095 * * *$} & \multicolumn{2}{|c|}{$46.218^{* * *}$} & \multicolumn{2}{|c|}{$85.329 * * *$} & \multicolumn{2}{|c|}{$8.640 * * *$} & \multicolumn{2}{|c|}{$7.116 * * *$} & \multicolumn{2}{|c|}{$13.752 * * *$} \\
\hline \multicolumn{2}{|c|}{ M2-F (Sig.) } & \multicolumn{2}{|c|}{$39.789 * * *$} & \multicolumn{2}{|c|}{$35.699 * * *$} & \multicolumn{2}{|c|}{$64.223 * * *$} & \multicolumn{2}{|c|}{$6.818 * * *$} & $5.943 * *$ & & 12.018 & \\
\hline $\mathrm{M} 2 / \mathrm{M} 1 \mathrm{~F}$ & var. (Sig.) & $3.578 * *$ & & $2.729 *$ & & 0.962 & & 1.305 & & 2.265 & & $5.677^{*}$ & \\
\hline
\end{tabular}

$* p<0.10 ; * * p \leq 0.05 ; * * * p \leq 0.001$ 
Table 5. Interaction effects (model 3)

\begin{tabular}{|c|c|c|c|c|c|c|c|c|c|c|c|c|}
\hline \multirow[t]{2}{*}{$(\mathrm{N}=346)$} & \multicolumn{2}{|c|}{ SEARCH } & \multicolumn{2}{|l|}{ BOOK } & \multicolumn{2}{|l|}{ WOM } & \multicolumn{2}{|c|}{ CONTENT } & \multicolumn{2}{|c|}{ FEEDBACK } & \multicolumn{2}{|c|}{ REFERRALS } \\
\hline & $\beta$ (St.) & t-value & $\beta$ (St.) & t-value & $\beta$ (St.) & t-value & $\beta$ (St.) & t-value & $\beta$ (St.) & t-value & $\beta$ (St.) & t-value \\
\hline Constant & & $2.877 * * *$ & & $2.408 * *$ & & 1.224 & & $\begin{array}{l}-0.999 \\
\end{array}$ & & -1.112 & & 1.091 \\
\hline SELF & 0.300 & $3.374 * * *$ & 0.228 & $2.524 * *$ & -0.020 & -0.259 & 0.210 & $1.822 *$ & 0.278 & $2.390 * *$ & 0.059 & 0.539 \\
\hline SAT & 0.321 & $3.567 * * *$ & 0.328 & $3.567 * * *$ & 0.773 & $9.904 * * *$ & 0.265 & $2.271 * *$ & 0.218 & $1.852 *$ & 0.469 & $4.250 * * *$ \\
\hline GENX & 0.134 & $2.487 * *$ & 0.089 & 1.625 & 0.003 & 0.072 & 0.070 & 1.003 & 0.122 & $1.734^{*}$ & -0.162 & $-2.453 * *$ \\
\hline GENY & 0.076 & 1.467 & 0.095 & $1.802 *$ & 0.016 & 0.352 & 0.055 & 0.825 & 0.060 & 0.884 & -0.093 & -1.467 \\
\hline SELFXSAT & 0.021 & 0.244 & 0.085 & 0.991 & 0.000 & 0.003 & -0.010 & -0.089 & -0.056 & -0.509 & -0.021 & -0.206 \\
\hline SELFXGENX & 0.044 & 0.543 & 0.058 & 0.698 & 0.191 & $2.717 * * *$ & 0.134 & 1.275 & 0.013 & 0.119 & 0.008 & 0.084 \\
\hline SELFxGENY & -0.048 & -0.714 & -0.097 & -1.404 & 0.027 & 0.463 & 0.063 & 0.722 & -0.048 & -0.536 & -0.085 & -1.026 \\
\hline SATxGENX & -0.014 & -0.170 & 0.036 & 0.437 & -0.156 & $-2.232 * *$ & -0.189 & $-1.799 *$ & -0.122 & -1.153 & -0.127 & -1.286 \\
\hline SATxGENY & 0.125 & $1.801^{*}$ & 0.145 & $2.051 * *$ & -0.060 & -0.989 & -0.055 & -0.611 & 0.005 & 0.056 & -0.018 & -0.210 \\
\hline SELFxSATxGENX & -0.053 & -0.681 & -0.022 & -0.279 & -0.087 & -1.275 & 0.044 & 0.437 & 0.020 & 0.195 & -0.047 & -0.487 \\
\hline SELFXSATxGENY & 0.051 & 0.732 & 0.010 & 0.148 & -0.004 & -0.063 & 0.077 & 0.848 & 0.114 & 1.252 & -0.116 & -1.357 \\
\hline Adjusted R2 & 0.473 & & 0.452 & & 0.605 & & 0.114 & & 0.097 & & 0.210 & \\
\hline F (Sig.) & $21.653 *$ & & $19.987^{\prime}$ & & 36.170 & & $3.973 *=$ & & $3.471 * *$ & & $7.119 *$ & \\
\hline F var. $(\text { Sig. })^{1}$ & 0.956 & & 1.558 & & $2.232 *$ & & 0.761 & & 0.689 & & 1.405 & \\
\hline
\end{tabular}

Note: F-var. compare the full model against the model that only includes direct effects. 